\title{
ENGLISH SUMMARY
}

The Swedish Institute for Children's Books publishes Barnboken - tidskrift för barnlitteraturforskning (Barnboken - Journal of Children's Literature Research) semiannually. It contains articles and essays on children's literature by specialists in the field, and provides information on reference books and theoretical works recently published and acquired by the library of the Institute

Helene Høyrup: Theory and Profession. Visions for Danish children's literature studies in the knowledge and media society

In the century of the child, the study of children's literature in Denmark was delayed by the absence of a higher educational and scientific infrastructure. This article argues that in our contemporary media and knowledge society it should be a high social priority to design educational structures that promote interaction between theory and professional practice and between the primary, secondary and tertiary levels of education. The article outlines some of the institutional constraints on the study of children's literature and discusses the historical causes and social implications of the relatively late academic institutionalisation in Denmark. The media and knowledge society generally necessitates the availability of higher educational levels. The final part of the article envisions children's literature studies as part of a multimodal, interdisciplinary programme of childhood studies dealing, for instance, with reading as a ludic and critical process, with literacies across media and with the textual play of signifier and signified.

Åse Marie Ommundsen: A world of permanent change translated into children's literature. The post-secular age reflected in late modern Norwegian children's literature

The idea of a post-secular age is reflected in late modern Norwegian children's literature. At the beginning of the new millennium religious matters have found their way back into literature. This fact might be seen as a movement of religious matters from the periphery toward the centre. Philosopher Jürgen Habermas and theologian and currently Pope, Joseph Ratzinger both claim that the events of recent years show that we are living in a new situation where religion plays an increasingly important role. In what ways are new 
religious questions raised in Norwegian children's literature? What existential questions are raised, and what answers are suggested? Two examples are discussed: Bjørn Sortland's novel 12 ting som må gjerast rett før verda går under (12 Things that have to be done before the world goes under, 2001) and Hans Sande and Gry Moursund's picture book Frosken (The frog, 2003). These two children's books ask similar existential questions, but the answers they suggest are different. In the first book something beyond mankind is suggested as a solution: the Christian God. In the other God is dead, and the solution is to use common sense and find the answer inside

\section{Anna-Maija Koskimies-Hellman: Threatening adults in empowering} fantasies

This article provides an analysis and comparison of two picture books, Inger Edelfeldt's Genom den röda dörren, eller Sagan om den lilla flickan, Grätkungen och Lejonpojken (Through the red door or The story of the little girl, the weeping king and the lion lad, 1992) and Tarja Lapintie's Kiveen kätketty linna (The stone castle, 1992). Using the power of their imaginations, two young girls break down the dullness of everyday life and move out of reality and into a new world. Both books follow the traditional carnivalesque pattern of children's literature, and the carnival theories of Michail Bachtin are used in the article to highlight power relations in both books. The carnival structure and the shifting positions of power also reflect the maturation processes of the protagonists and, according to the author of the article, both adventure stories may be read as a symbolic level as portrayals of the interior worlds of the two girls. Using the carnival structure, attention is focused on the empowering function of the adventures, as well as on another aspect of power: the clash between children and adults, which becomes central to both books in terms of both content and form. Threats and safety are embodied in adults in the work of both Edelfeldt and Lapintie. The reverse sides of good parents are personified in the captors. Although their imaginations are empowering to the protagonists, they are not released from their positions of inferioity as children even after the end of their adventures. In this respect both books are tradition-bound. However, in spite of the conventioal circular form of both books, neither Edelfeldt nor Lapintie are conventional in their characterizations. These fantasy tales both contain interesting characters with complex personalities. This also shows what an optimal medium picture books are for the description of complex characters and their states of mind. 